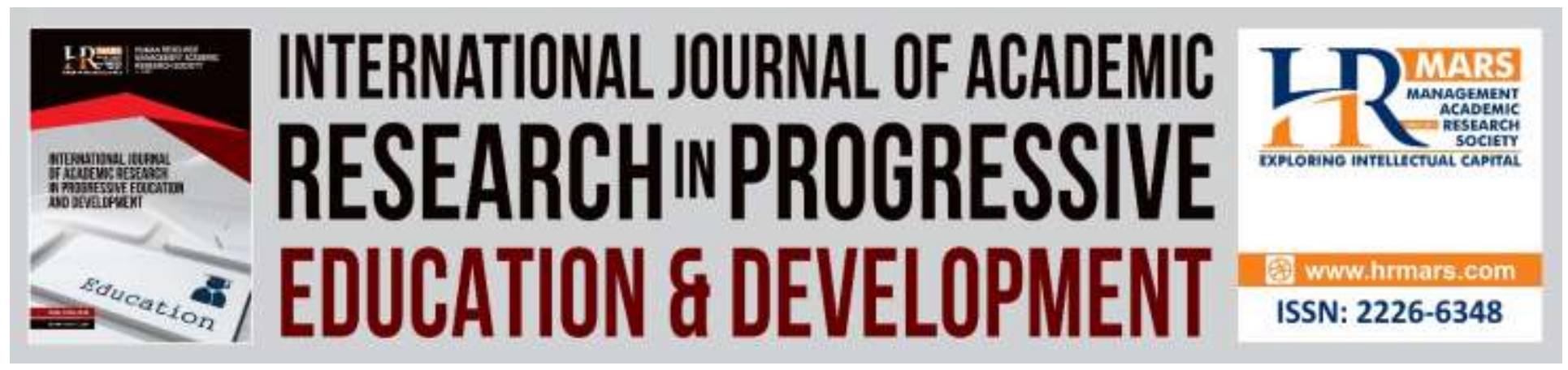

\title{
The Influence of Special Education Training on Teachers' Attitudes towards Inclusive Education: Case Study in Aceh Province, Indonesia
}

Istiarsyah, Amir Hasan Dawi, Noor Aini Ahmad

To Link this Article: http://dx.doi.org/10.6007/IJARPED/v8-i4/6901

DOI:10.6007/IJARPED/v8-i4/6901

Received: 15 October 2019, Revised: 22 November 2019, Accepted: 15 December 2019

Published Online: 29 December 2019

In-Text Citation: (Istiarsyah et al., 2019)

To Cite this Article: Istiarsyah, Dawi, A. H., \& Ahmad, N. A. (2019). The Influence of Special Education Training on Teachers' Attitudes towards Inclusive Education: Case Study in Aceh Province, Indonesia. International Journal of Academic Research in Progressive Education and Development, 8(4), 1016-1027.

Copyright: (C) 2019 The Author(s)

Published by Human Resource Management Academic Research Society (www.hrmars.com)

This article is published under the Creative Commons Attribution (CC BY 4.0) license. Anyone may reproduce, distribute, translate and create derivative works of this article (for both commercial and non-commercial purposes), subject to full attribution to the original publication and authors. The full terms of this license may be seen at: http://creativecommons.org/licences/by/4.0/legalcode

Vol. 8(4) 2019, Pg. 1016 - 1027

http://hrmars.com/index.php/pages/detail/IJARPED

JOURNAL HOMEPAGE

Full Terms \& Conditions of access and use can be found at http://hrmars.com/index.php/pages/detail/publication-ethics 


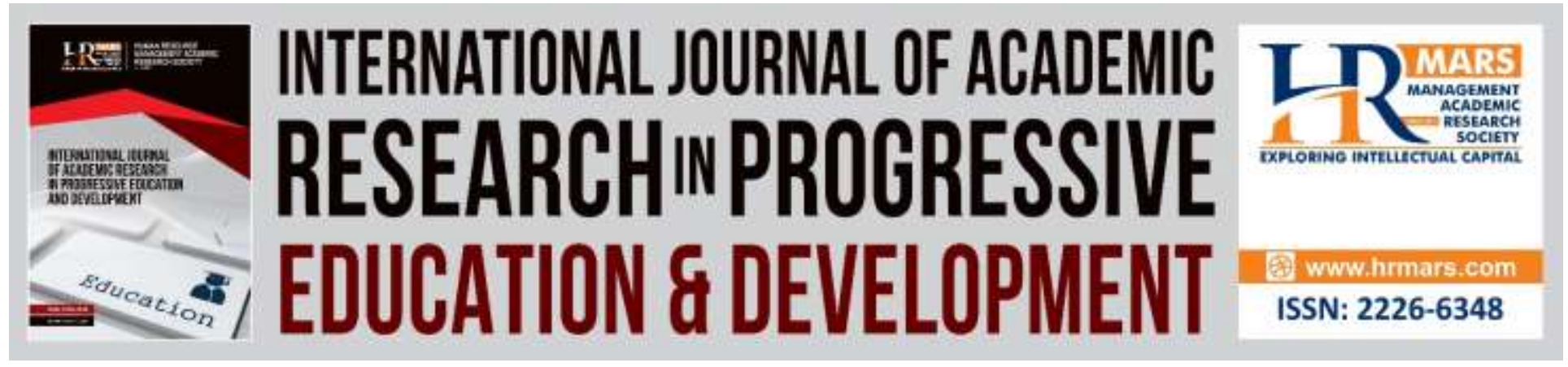

\title{
The Influence of Special Education Training on Teachers' Attitudes towards Inclusive Education: Case Study in Aceh Province, Indonesia
}

\author{
Istiarsyah, Amir Hasan Dawi, Noor Aini Ahmad \\ Faculty of Human Development, Universiti Pendidikan Sultan Idris, 35900 Tanjong Malim, \\ Perak Darul Ridzuan, Malaysia \\ Email: istiarsyah@yahoo.co.id, amir.hasan@fpm.upsi.edu.my,noor.aini@fpm.upsi.edu.my
}

\begin{abstract}
Inclusive education as a primary education policy for students with special needs to create inclusive society and equal opportunities in education. The purpose of this study was to identify the attitude of Primary School teachers towards inclusive education in Aceh province. Attitude assessment consists of three aspects: cognitive, affective, and behavioral, and how special education training influence teachers' attitudes toward inclusive education. This study involved 399 primary school teachers. The results of the MANOVA test revealed there was a significant difference effect of teachers who have received in special education training on all aspects of attitude with the Wilks' Lambda $\lambda$ value $[F$ dk $(3,395)=0.909$, sig $=0.000 p<0.05]$. Whereas the results of the ANOVA analysis found there were a significant effect differences on two of the three aspects of attitude, there are in cognitive aspect $[F d k(1,397)=26.129$, with sig $=0.000 p$ $<0.05]$ and in behavioral aspect $[\mathrm{F} \mathrm{dk}(1,397)=35.360$, with sig $=0.000 \mathrm{p}<0.05]$, while there was no significant effect difference on the affective aspect $[F d k(1,397)=0.776$, with sig $=0.379 p>$ 0.05]. The study concludes that special education training in inclusive education practices enhances teachers' confidence in their ability to work with special needs children as well as enhances their effectiveness in implementing classroom practices, which is a contributing factor to success in inclusive education. The implications of the study indicate that there is a need for improved training programs for teachers teaching in inclusive education schools in Aceh province so that inclusive education practices can work as determined by the Indonesian government.
\end{abstract}

Keywords: Attitudes, Special Needs Children, Special Education, Inclusive Education

\section{Introduction}

The education system of special need students in Indonesia might be similar with another Asian country or even European. Most (developing) countries have separate education system to distinguish normal and special need student or impairment. Sunardi, Maryadi, and Sugini (2014) 
have reported that, in Indonesia, special need schools mostly located in the city, whereas special need students are everywhere, either in the village or haunted area. This condition leads an obstacle for them to access the education. Fortunately, the awareness to provide an effective education for these students are increasing currently in some countries (Kantavong, 2017). Hence, the term of "Inclusive Education" has revealed and became as solution regarding to the education justice development to fulfill the special student education needs. Along with the development of demands for rights in obtaining justice in education, the concept of inclusive education emerged as an equalization of education for students with specific abilities to develop their own potential. The Salamanca Statement and Framework for Action on Special Needs Education in 1994 more explicitly demanded that education for students with special characteristics be inclusive, so that the education system that separates individuals and their communities is a violation of human rights (UNESCO, 1994).

Teacher attitudes may fulfill the need of special needs students during inclusive education practices in the classrooms. This aspect has become as variables that affecting inclusive education (Vaz, Wilson, Falkmer, Sim, Scott, Cordier, and Falkmer, 2015; Gennaro, Pace, Zollo, and Aiello 2014; Monsen, Ewing, and Kwoka, 2014; Engstrand and Roll-Pettersson, 2014; Malak, 2013; Sushma and Smriti, 2012). Cassady (2011) has emphasized the importance of identifying the teacher's attitude toward inclusive education, because negative attitudes inhibit their achievement and degree of success. Teachers' positive attitude is the most important aspect that contributes the major benefit toward the achievement of inclusive education practice (Yaraya, Masalimova, Vasbieva and Grudtsina , 2018; Pappas, Papoutsi, and Drigas 2018; Yada and Savolainen, 2017; Ahmme et al., 2013; Bhatnagar, Nisha, and Das, 2014; Dias and Cadime, 2016; Shoulders and Krei, 2014; Lee, Yeung, Tracey, and Barker, 2015; Lee, 2013; Rajovic and Juranovic, 2013; Salem, 2013; Khochen and Radford, 2012; Firat, 2014; Peter and Nderitu, 2014). Furthermore, attitude has become as important factor to achieve the inclusive education toward implementation successfully (Dorji, Bailey, Paterson, Graham, and Miller, 2019; Fernández, and Cortés, 2017; Hoskin, Boyle, and Anderson, 2015).

Teacher training program becomes very important during conducting the inclusive education practice. It's not only facilitate or enhance teachers' confidence and their ability to work with special needs students who need special education, but also may increase their effectiveness to implement inclusive education practices in the classroom. The teachers who experienced the training of inclusive education practice and training to work with special needs students have more positive attitude to accept the inclusive education than the teachers who are not (Akalin et al., 2014, Forlin, Sharma, Loreman, and Sprunt, 2015; Odongo and Davidson, 2016; Priyadarshini and Thangarajathi, 2016; Sandhu, 2017; Vaz et al., 2015). The majority of teachers expressed their concerns about the lack of training and professional development in inclusive teaching practices in the classroom, and subsequently influenced their ability to succeed in providing an inclusive learning environment (Akalin et al., 2014, Forlin et al. 2015; Nketsia, Saloviita and Gyimah, 2016; Odongo and Davidson, 2016; Vaz et al., 2015). The training of special education orientation may influence the positive impact of attitude toward inclusive education (Cameron, 
INTERNATIONAL JOURNAL OF ACADEMIC RESEARCH IN PROGRESSIVE EDUCATION AND

DEVELOPMENT

Vol. 8, No. 4, 2019, E-ISSN: 2226-6348 @ 2019 HRMARS

2017). Thus, teacher training program about inclusive education is the major factor that contributes the teacher's attitude toward a successful inclusive education program.

The aim of this study was to measure the influence of special education training on teachers' attitudes towards inclusive education in Aceh province. According to this purpose of study, the research question was, "Is there any significant differences between teachers who have received special education training and those who have not been trained in attitude aspects (cognitive, affective, and behavioral) toward inclusive education? The hypothesis of currents study, as follows:

Ho1.1 There is no significant differences between teachers who have received special education training and those who have not been trained in cognitive aspects toward inclusive education.

Ho1.2 There is no significant differences between teachers who have received special education training and those who have not been trained in affective aspects toward inclusive education.

Ho1.3 There is no significant differences between teachers who have received special education training and those who have not been trained in behavioral aspects toward inclusive education.

\section{Research Method}

The quantitative method was utilized in this research, with the questionnaires as the research instrument. The questionnaire can be useful for collecting information on behaviors that are not directly visible. The use of questionnaires provided information based on descriptions, quantities, or opinions of the population on a quantitative or numerical basis by studying the sample of the population (Chua, 2014; Artino, Rochelle, Dezee, and Gehlbach, 2014). This means that the information collected from the questionnaire can be calculated so that the description of the target population can be made. Population and sample of current study were Elementary School Teachers. Moreover, the population of current study was 10,663 Elementary School Teachers who came from three different districts in Aceh. Random sampling method was applied according to sample size formula by Slovin in Savilla et. Al., (2007). Thus, there were 399 Elementary School Teachers, from those 3 different areas or districts in Aceh Province, who conducting inclusive education have become the participants who joined in this study $(p=0.05)$. Table 1.1 describes the total sample size, 399 teachers. For each region using a layered sampling formula according to Azizi Yahya et al. (2006) is $S=(Z \div N) \times n 1$, where $Z$ represents the total sample volume, $N$ total pollutant volume, while $\mathrm{n} 1$ represents the total population per region. 
Table 1.1: Total of Sample Size from three Districts in Aceh

\begin{tabular}{llllll}
\hline \multirow{2}{*}{ No. } & \multirow{2}{*}{ Districts } & \multicolumn{2}{l}{ Number of Teachers } & \multirow{2}{*}{ Overall total } & $\begin{array}{l}\text { Sample } \\
\text { Region }\end{array}$ \\
\cline { 2 - 5 } & Boys & Girls & & \\
\hline 1 & Aceh Besar & 421 & 2,183 & 2,604 & 97 \\
2 & Pidie & 698 & 3,436 & 4,134 & 155 \\
3 & Bireuen & 694 & 3,231 & 3,925 & 147 \\
\hline Overall total population & 1,813 & 8,850 & 10,663 & \\
\hline \multicolumn{7}{l}{ Saiz sampel } \\
\hline
\end{tabular}

Source: Kemendikbud (2016).

\section{Result and Discussion}

According to Table 1.2 below, the majority of the participants were female teachers at $83.0 \%$, $(n=331)$ while the remaining $17.0 \%$ were males $(n=68)$. According to the training experience, the majority of the participants were never been trained for special education training program $(82.7 \%, n=330)$, while only $17.3 \%(n=69)$ the participants were experienced for special education program, including inclusive education.

Table 1.2: Demography of Participants

\begin{tabular}{llcc}
\hline Demografi & Participants & Frequency $(f)$ & Precentage (\%) \\
\hline Gender & Male & 68 & 17.0 \\
& Female & 331 & 83.0 \\
\hline Special Education Training & Trained & 69 & 17.3 \\
Experience & Never be Trained & 330 & 82.7 \\
\hline
\end{tabular}

According to the table 1.3, MANOVA analysis result showed there was statistical significant differences, before and after, teachers' training on all domains of teachers attitude with Wilks' Lambda $\lambda[\mathrm{F} \mathrm{dk}(3,395)=0.909$, sig $=0.00 \mathrm{p}<0.05])$. MANOVA result reported that there was significant impact of teacher training toward teachers' attitude, all in cognitive, affective and psychomotor domains among Elementary School teachers toward inclusive education, thus null hypothesis was rejected.

Table 1.3

The MANOVA test shows the influence of Special Education Training on overall of attitude aspects

\begin{tabular}{lllll}
\hline Effect & & $\begin{array}{c}\text { Value Hypothesis } \\
\text { Df }\end{array}$ & Error df & Sig. \\
\hline Special Education & Pillai's Trace & 0.0913 .000 & 395.000 & 0.000 \\
Training & Wilks' Lambda & 0.9093 .000 & 395.000 & 0.000 \\
& Hotelling's Trace & 0.1003 .000 & 395.000 & 0.000 \\
& Roy's Largest Root & 0.1003 .000 & 395.000 & 0.000 \\
\hline
\end{tabular}


One-Way Univariate ANOVA analysis test has been applied to measure the detail impact of teacher training program on cognitive, affective and psychomotor domains. Table 1.4 reported that there was significant influence of teacher training program on those three domains, hence minor hypothesis, Ho1.1, Ho1.2, and Ho1.3 were accepted.

Ho1.1 There is no significant differences between teachers who have received special education training and those who have not been trained on cognitive aspect toward inclusive education. Table 1.4 reported that, there was significant differences between who have received special education training and those who have not been trained on cognitive aspect toward inclusive education $[F d k(1,397)=26.12$, sig $=0.00 p<0.05] . R^{2}$ Squared value indicate that teacher who have received special education training contributed for 0.062 or 6.2 percent change in the cognitive aspect.

Ho1.2 There is no significant differences between teachers who have received special education training and those who have not been trained on cognitive aspect toward inclusive education. Table 1.4 reported that, there was significant differences between who have received special education training and those who have not been trained on affective aspect toward inclusive education $[F d k(1,397)=0.77$, sig $=0.37 p>0.05]$. $R^{2}$ Squared indicate that teacher who have received special education training contributed for 0.002 or 0.2 percent change in the affective aspect.

Ho1.3 There is no significant differences between teachers who have received special education training and those who have not been trained on behavioural aspects toward inclusive education. Table 1.4 reported that, there was significant differences between who have received special education training and those who have not been trained on behavioural aspects toward inclusive education $[\mathrm{F} \mathrm{dk}(1,397)=35.36$, dengan sig $=0.00 p<0.05]$. $\mathrm{R}^{2}$ Squared indicate that teacher who have received special education training contributed for for 0.082 or 8.2 percent change in the behavioural aspect.

Table 1.4:

ANOVA analysis test for the teachers who have been trained in special education training on cognitive, affective and psychomotor aspect.

\begin{tabular}{lllllllll}
\hline $\begin{array}{l}\text { Dependent } \\
\text { Variable }\end{array}$ & $\begin{array}{l}\text { Special Education } \\
\text { Training }\end{array}$ & $\mathrm{N}$ & Mean & $\begin{array}{l}\text { Mean } \\
\text { Square }\end{array}$ & df1/df2 & Error & $\mathrm{F}$ & Sig. \\
\hline Cognitive & Trained & 69 & 3.774 & 6.851 & $1 / 397$ & 0.262 & 26.129 & 0.000 \\
& Never be Trained & 330 & 3.428 & & & & & \\
affective & Trained & 69 & 3.258 & 0.250 & $1 / 397$ & 0.323 & 0.776 & 0.379 \\
& Never be Trained & 330 & 3.192 & & & & & \\
Behavioural & Trained & 69 & 4.059 & 8.857 & $1 / 397$ & 0.250 & 35.360 & 0.000 \\
& Never be Trained & 330 & 3.665 & & & & & \\
\hline
\end{tabular}

a. $\mathrm{R}$ Squared $=.062$ (Adjusted R Squared $=.059$ )

b. Squared $=.002$ (Adjusted R Squared $=-.001$ ) 


\section{c. Squared $=.082$ (Adjusted R Squared $=.079)$}

Line of graph on Figure 1.1 concludes the mean score of participants who have been trained in special education training on cognitive, affective, and behavioural aspects. The mean of cognitive aspect for teachers who have been trained in special education training was higher $(M=3.77)$ than the teachers who have not been trained $(M=3.42)$. However, mean scores for both groups of participants have showed the convenient scores on cognitive domain (3.41-4.20 = convenient). While, the mean score of affective aspect for teachers who have not been trained in special education training was higher $(M=3.25)$ than the teachers who have been trained $(M=3.19)$. However, mean scores for both groups of participants have showed the avarage scores on affective domain. (2.61-3.40 = average). In other side mean score of behavioural aspect for teachers who who have been trained in special education training was higher $(M=4.05)$ than the teachers who have not been trained $(M=3.66)$. However, mean scores for both groups of participants have showed the convenient scores on behavioural aspect. (3.41-4.20= convenient).
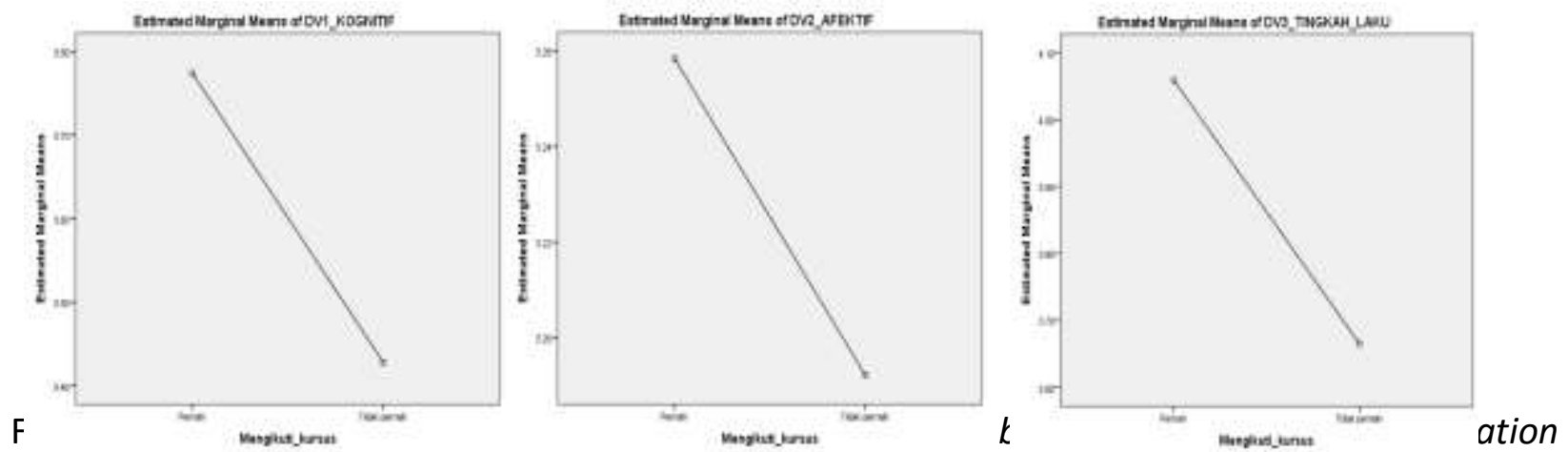

training on cognitive, affective, and behavioural aspects.

Table 1.5 has showed the results of Pairwise Comparison Bonferroni test, as there was significant differences between two groups teachers who teachers who have been trained in special and who were not on cognitive, affective and behavioural aspects toward inclusive education. The data analysts results reported that, there was significant differences between two groups of participants who have been trained in special and who were not on cognitive domain, with mean differences was 0.346, sig $0.00 p<0.05$. While in behaviour aspect there was a significant difference who have been trained in special and who were not with mean difference 0.394 , sig $0.00 \mathrm{p}<0.05$. 
INTERNATIONAL JOURNAL OF ACADEMIC RESEARCH IN PROGRESSIVE EDUCATION AND

DEVELOPMENT

Vol. 8, No. 4, 2019, E-ISSN: 2226-6348@ 2019 HRMARS

Table 1.5

Comparison of Pairwise Comparison Bonferroni by Special Education Training on Attitude Aspects

\begin{tabular}{|c|c|c|c|c|c|c|c|}
\hline \multirow{2}{*}{$\begin{array}{l}\text { Dependent } \\
\text { Variable }\end{array}$} & \multicolumn{2}{|c|}{ Groups } & \multirow{2}{*}{$\begin{array}{l}\text { Mean } \\
\text { Differenc } \\
(I-J)\end{array}$} & \multirow{2}{*}{$\begin{array}{l}\text { Std. } \\
\text { e Error }\end{array}$} & \multirow{2}{*}{ Sig. } & \multicolumn{2}{|c|}{$\begin{array}{l}\text { 95\% Confidence } \\
\text { Interval }\end{array}$} \\
\hline & (I) & (J) & & & & $\begin{array}{l}\text { Lower } \\
\text { Bound }\end{array}$ & $\begin{array}{l}\text { Upper } \\
\text { Bound }\end{array}$ \\
\hline \multirow[t]{2}{*}{ Cognitive } & Trained & Never be Trained & $0.346^{*}$ & 0.068 & 0.000 & 0.213 & 0.480 \\
\hline & Never be Trained & Trained & $-0.346^{*}$ & 0.068 & 0.000 & -0.480 & -0.213 \\
\hline \multirow[t]{2}{*}{ affective } & Trained & Never be Trained & 0.066 & 0.075 & 0.379 & -0.082 & 0.214 \\
\hline & Never be Trained & Trained & -0.066 & 0.075 & 0.379 & -0.214 & 0.082 \\
\hline \multicolumn{2}{|c|}{$\begin{array}{l}\text { BehaviouralTrained } \\
\text { Never be Trained }\end{array}$} & $\begin{array}{l}\text { Never be Trained } \\
\text { Trained }\end{array}$ & $\begin{array}{l}0.394^{*} \\
-0.394^{*}\end{array}$ & $\begin{array}{l}0.066 \\
0.066\end{array}$ & $\begin{array}{l}0.000 \\
0.000\end{array}$ & $\begin{array}{c}0.264 \\
-0.524\end{array}$ & $\begin{array}{c}0.524 \\
-0.264\end{array}$ \\
\hline
\end{tabular}

Based on estimated marginal means

*. The mean difference is significant at the, 05 level.

b. Adjustment for multiple comparisons: Bonferroni.

Overall the results of the data analysis in this section rejected the first null hypothesis because the MANOVA test showed that there were significant effects of course followings on all aspects of attitude (cognitive, affective, and behavioral aspects) where Wilks' Lambda $\lambda[\mathrm{F} \mathrm{dk}(3,395)=$ 0.90 , sig $=0.00 \mathrm{p}<0.05$ ]. This indicates that special education training has a significant influence on teachers' attitudes in the cognitive, affective, and behavioral aspects. While the results of the univariate test analysis revealed that there were significant effects of training on two of three attitude aspects in cognitive aspects $[\mathrm{F} \mathrm{dk}(1,397)=26.12$, with sig $=0.000 p<0.05]$ and behavioral aspects $[\mathrm{F} \mathrm{dk}(1,397)=35.36$, with sig $=0.000 \mathrm{p}<0.05]$, then Ho1.1 and Ho1.3 were rejected, but there was no significant effect of special education training on affective aspects $[F \mathrm{dk}(1,397)=$ 0.776 , with sig $=0.37 \mathrm{p}>0.05$ ], then Ho1.2 is accepted. Therefore, it is concluded that special education training has a significant influence on teachers' attitude towards inclusive education.

The findings of this research is parallel of the other studies found that teachers who receive special education in inclusive education practices have a more positive attitude toward inclusive education than teachers who were not (Akalin et al., 2014, Forlin and Chambers, 2011; Odongo and Davidson, 2016; Priyadarshini and Thangarajathi, 2016; Sandhu, 2017; Vaz et al., 2015). Akdag and Haser (2017); Chavez-Bernardo, (2014) conducted a study in Turkey found that teachers showed a positive attitude after embracing special education training. Special education training fosters positive attitude for Slovenian Primary teachers (Štemberger and Kiswarday (2018). Lai, Lee, Nor Lisa, Mimi Mohaffyza and Kahirol (2017) conducted a study in Johor, Malaysia on 128 teaching teachers Special needs students in mainstream schools are actively involved in inclusive education programs. The result shows that there is an increase in the level of readiness in terms of pedagogical skills, as well as good knowledge and attitude. Teachers will 
able to work with special needs children inthe classroom, and has shown great knowledge to teach in inclusive programs (Bari, Yasin and Hamzah, 2014; Abdullah, \& Mustafa, 2018; Anghel, Mirea, Badiu, (2018).

\section{Conclusion}

Implementing inclusive education is a challenging task because teachers involved in inclusive education must be equipped with special education knowledge and pedagogical skills, and more importantly, teachers' positive attitude toward special needs students in mainstream schools, as well as high spirit of inclusive education. Teachers are not only required to master new knowledge but also to acquire knowledge constantly. Support from schools and the Education Department in the form of training is one of the most effective ways to equip teachers with knowledge. In addition, it is even more important for teachers to engage in learning directed to gain deeper knowledge. Teacher knowledge plays an important role in creating an effective and conducive learning environment and critically influences the development of inclusive education. Teachers' ability to design the Individual Educational Program (IEP) in terms of teaching skills, attitudes and knowledge needs to be enhanced to ensure IEP is a successful and sustainable program. Therefore, special education that is successful in the mainstream will depend on the attitude, knowledge and skills of the teachers, techniques and teaching materials. However, researchers suggest that innovations in teaching and practical training in special education schools still need to be provided to provide teachers with a more realistic experience.

\section{References}

Anghel, M.-G., Mirea, M., Badiu, A. (2018). Analysis of the Main Aspects Regarding the Price Indices Applied in the Determination of Inflation, International Journal of Academic Research in Accounting, Finance and Management Sciences 8 (2): 28-36

Abdullah, C. Z. H., \& Mustafa, N. A. (2018). Halal Information among Muslim Travelers and Tourist-Driven Industry. International Journal of Academic Research in Progressive Education and Development, 7(3), 178-186.

Ahmmed, M., Sharma, U., \& Deppeler, J. (2013). Impact of demographic variables and school support on teacher efficacy in inclusive classrooms in Bangladesh. The International Journal of Diversity in Education, 12(2), 1-14.

Akalin, S., Demir, S., Sucuoglu, B., Bakkaloglu, H., \& Iscen, F. (2014). The Needs of Inclusive Preschool Teachers about Inclusive Practices. Eurasian Journal of Educational Research, 54, 39-60.

Akdağ, Z., \& Haser, Ç. (2017). Beginning early childhood education teachers' struggle with inclusion in Turkey. Asia Pacific Journal of Education, 37(2), 219-231.

Jr, A. R., Rochelle, L. J. S., Dezee, K. J., Gehlbach, D. H. (2014). Developing questionnaires for educational research: AMEE Guide No. 87. Medical teacher, 36(6), 463-474.

Yahya, A., Hashim, S., Ramli, J., Hamdan, Yusuf B. D. A. R. (2006). Menguasai Penyelidikan dalam Pendidikan. Kuala Lumpur: PTS Professional Publishing, Sdn. Bhd.

Bari, S., Yasin, M. H. M., \& Hamzah, M. N. (2014). The Readiness of Special Education Trainees to Teach in Inclusive Program. International Education Studies, 7(13), 206-211. 
INTERNATIONAL JOURNAL OF ACADEMIC RESEARCH IN PROGRESSIVE EDUCATION AND

DEVELOPMENT

Vol. 8, No. 4, 2019, E-ISSN: 2226-6348 @ 2019 HRMARS

Bhatnagar, N., \& Das, A. (2014). Attitudes of secondary school teachers towards inclusive education in N ew D elhi, I ndia. Journal of Research in Special Educational Needs, 14(4), 255-263.

Cameron, D. L. (2017). Teacher preparation for inclusion in Norway: a study of beliefs, skills, and intended practices. International Journal of Inclusive Education, 21(10), 1028-1044.

Cassady, J. (2011). Teachers' attitudes toward the inclusion of students with autism and emotional behavioral disorder. Electronic Journal for Inclusive Education, 2(7), 1-23.

Chua, Y. P. (2014). Kaedah Penyelidikan: Kaedah dan Statistik Penyelidikan (Edisi 3). Kuala Lumpur: Mcgraw-Hill Sdn. Bhd.

CHAVEZ-BERNARDO, A. (2014). Students' On-the-Job-Training Performance of AB Paralegal Studies. Multilingual Academic Journal of Education and Social Sciences, 2(2), 28-36.

Istiarsyah, Dawi, A. H., \& Ahmad, N. A. (2019). The Influence of Special Education Training on Teachers' Attitudes towards Inclusive Education: Case Study in Aceh Province, Indonesia. International Journal of Academic Research in Progressive Education and Development, 8(4), 977-988.

Gennaro, D. C., Pace, E. M., Zollo, I., Aiello, D. P. (2014). Teacher Capacity Building Through Critical Reflective Practice for the Promotion of Inclusive Education. Problems of Education in the 21st Century, 60.

Dias, P. C., dan Cadime, I. (2016). Effects of personal and professional factors on teachers' attitudes towards inclusion in preschool. European Journal of Special Needs Education, 31(1), 111-123.

Dorji, R., Bailey, J., Paterson, D., Graham, L., \& Miller, J. (2019). Bhutanese teachers' attitudes towards inclusive education. International Journal of Inclusive Education, 1-20.

Engstrand, R. Z., dan Roll-Pettersson, L. (2014). Inclusion of preschool children with autism in Sweden: Attitudes and perceived efficacy of preschool teachers. Journal of Research in Special Educational Needs, 14(3), 170-179.

Fernández, C. C., dan Cortés, C. M. A. C. (2017). Alternative teaching practices for inclusive education. In SHS Web of Conferences (Vol. 37, p. 01005). EDP Sciences.

Firat, T. (2014). An investigation on attitudes of teacher candidates who will work at different education levels towards mainstreaming. Journal of Adıyaman University Social Sciences Instution, 7(18), 597-628.

Forlin, C., Sharma, U., Loreman, T., dan Sprunt, B. (2015). Developing disability-inclusive indicators in the Pacific Islands. Prospects, 45(2), 197-211.

Hoskin, J., Boyle, C., dan Anderson, J. (2015). Inclusive education in pre-schools: predictors of preservice teacher attitudes in Australia. Teachers and Teaching, 21(8), 974-989.

Khochen, M., dan Radford, J. (2012). Attitudes of teachers and head teachers towards inclusion in Lebanon. International Journal of Inclusive Education, 16(2), 139-153.

Lai, C. S., Lee, M. F., Nor Lisa, S., Mimi Mohaffyza, M., \& Kahirol, M. S. (2017). Involvement of Mainstream Teachers in Inclusive Education: Are We Ready?. Pertanika Journal of Social Science and Humanities, 25, 205-214.

Lee, F. L. M., Yeung, A. S., Tracey, D., \& Barker, K. (2015). Inclusion of children with special needs in early childhood education: What teacher characteristics matter. Topics in Early Childhood Special Education, 35(2), 79-88. 
INTERNATIONAL JOURNAL OF ACADEMIC RESEARCH IN PROGRESSIVE EDUCATION AND

DEVELOPMENT

Vol. 8, No. 4, 2019, E-ISSN: 2226-6348 @ 2019 HRMARS

Lee, S. E. (2013). Professional development and teacher perception of efficacy for inclusion. Doctoral dissertation. Available from ProQuest Dissertations dan Theses database. (UMI No. 3570295).

Malak, S. (2013). Inclusive education reform in Bangladesh: Pre-service teachers' responses to include students with special educational needs in regular classrooms. International Journal of Instruction, 6(1), 195-214.

Monsen, J. J., Ewing, D. L., dan Kwoka, M. (2014). Teachers' attitudes towards inclusion, perceived adequacy of support and classroom learning environment. Learning Environments Research, 17(1), 113-126.

Nketsia, W., Saloviita, T., dan Gyimah, E. K. (2016). Teacher Educators' Views on Inclusive Education and Teacher Preparation in Ghana. International Journal of Whole Schooling, 12.

Odongo, G. (2012). Caught between progress, stagnation and a reversal of some gains: Reflections on Kenya's record in implementing children's rights norms. African Human Rights Law Journal, 12(1), 112-141.

Odongo, G., \& Davidson, R. (2016). Examining the Attitudes and Concerns of the Kenyan Teachers toward the Inclusion of Children with Disabilities in the General Education Classroom: A Mixed Methods Study. International Journal of Special Education, 31(2), n2.

Pappas, M., Papoutsi, C., \& Drigas, A. (2018). Policies, Practices, and Attitudes toward Inclusive Education: The Case of Greece. Social Sciences, 7(6), 90.

Peter, M. N., \& Nderitu, M. N. (2014). Perceptions of teachers and head teachers on the effectiveness of inclusive education in public primary schools in Yatta Division Machakos County. Journal of Educational and Social Research, 4(1), 91.

Priyadarshini, S. S., \& Thangarajathi, S. (2017). Effect of Selected Variables on Regular School Teachers Attitude towards Inclusive Education. Journal on Educational Psychology, 10(3), 28-38.

Rajovic, V., dan Juranovic, O. (2013). The barriers of inclusive education: Mapping 10 years of Serbian teachers' attitudes toward inclusive education. Journal of Special Education and Rehabilitation, 14(3/4), 78-97.

Salem, A. A. (2013). The Impact of Teaching Academic Education Course of Children with Special Needs in the Ordinary Schools on Students' Attitudes toward Inclusion of Disabled Children. Journal of Education and Learning, 2(2), 112.

Sandhu, R. (2017). A study of attitude of secondary schools teachers toward inclusive education. Indian Journal of Health \& Wellbeing, 8(6).

Schmidt, M., and Ksenja, V. (2015). "Attitudes of Teachers Towards the Inclusion of Children with Special Needs in Primary and Secondary Schools." Hrvatska Revija za Rehabilitacijska Istrazivanja,51(2): 16-30.

Sevilla, Consuelo, G. (2007). Research Methods. Rex Printing Company. Quezon City.

Shoulders, T. L., dan Krei, M. S. (2014). Rural secondary educators' perceptions of their efficacy in the inclusion classroom. Rural Special Education Quarterly 35(1), 23-30.

Štemberger, T., \& Kiswarday, V. R. (2018). Attitude towards inclusive education: the perspective of Slovenian preschool and primary school teachers. European Journal of Special Needs Education, 33(1), 47-58. 
Sushma, S., Dan Smriti, B. (2012). In-Service Primary Teachers'attitude Towards Inclusion: Survey Results from District Kurukshetravv (HARYANA). Gyanodaya, 5(2), 25.

Vaz, S., Wilson, N., Falkmer, M., Sim, A., Scott, M., Cordier, R., dan Falkmer, T. (2015). Factors associated with primary school teachers' attitudes towards the inclusion of students with disabilities. PloS one, 10(8), e0137002.

Yada, A., Dan Savolainen, H. (2017). Japanese in-service teachers' attitudes toward inclusive education and self-efficacy for inclusive practices. Teaching and Teacher Education, 64, 222-229.

Yaraya, T. A., Masalimova, A. R., Vasbieva, D. G., \& Grudtsina, L. Y. (2018). The development of a training model for the formation of positive attitudes in teachers towards the inclusion of learners with special educational needs into the educational environment. South African Journal of Education, 38(2), 1-9. 